DOI: 10.17707/AgricultForest.65.1.06

\author{
Ivana GLIŠIÍ́*, Dragan MILATOVIĆ, Radosav CEROVIĆ, \\ Sanja RADIČEVIĆ, Milena ĐORĐEVIĆ, Nebojša MILOŠEVIĆ ${ }^{1}$
}

\title{
UNUSUAL GROWTH OF POLLEN TUBES IN THE OVARY OF PLUM GENOTYPES DEVELOPED AT FRUIT RESEARCH INSTITUTE ČAČAK (SERBIA)
}

\begin{abstract}
SUMMARY
Unusual growth of pollen tubes in different pollination variants (self-, cross- and open pollination) was observed in the ovary of six promising plum (Prunus domestica L.) genotypes developed at Fruit Research Institute (FRI), Čačak (hybrids 38/62/70, IV/63/81, 32/21/87, 34/41/87 and 22/17/87 and cultivar 'Nada') in Serbia. The cross-pollination was performed using the pollen of plum cultivar 'Čačanska Lepotica'. The occurrence of unusual pollen tubes growth in the ovary was studied over the three-year period (2009-2011) using fluorescent microscopy method. The appearance of unusual growth of pollen tubes in the ovary of all studied genotypes during the whole examination period was recorded in the region of the obturator and the micropyle, with or without further growth of the pollen tubes to the nucellus.

Several different types of unusual growth of pollen tubes were observed, i.e. the growth of pollen tubes in opposite direction in relation to the nucellus, the curling up of pollen tubes, the branching of pollen tubes, as well as combinations of some of the above mentioned types of specific pollen tubes growth. Average values of all analyzed genotypes showed that the highest frequency of the ovaries with unusual growth of pollen tubes was determined in the open pollination variant $(7.89 \%)$, followed by the cross-pollination variant $(6.27 \%)$, while the smallest frequency was found in the self-pollination variant (3.12\%).

Keywords: Prunus domestica L., promising genotypes, pollination variant, pollen tubes growth, ovary, unusual growth

\section{INTRODUCTION}

The efficiency of the pollen tubes growth in the style and in the ovary and the final outcome of pollination are influenced by a large number of factors. Thus, in this respect, Neumüller (2010) favours the influence of the female genotype, Stott et al. (1973) emphasize the effect of the pollination variant.

\footnotetext{
${ }^{1}$ Ivana Glišić*(corresponding author: iglisic@institut-cacak.org), Sanja Radičević, Milena Đorđević, Nebojša Milošević, Fruit Research Institute, Čačak, Kralja Petra I, 9, 32000 Čačak, Republic of SERBIA; Dragan Milatović, University of Belgrade, Faculty of Agriculture, Nemanjina 6, 11080 Belgrade, Republic of SERBIA; Radosav Cerović, Innovation Centre, Faculty of Technology and Metallurgy, Karnegijeva 4, 11120 Belgrade, Republic of SERBIA Paper presented at the $9^{\text {th }}$ International Scientific Agricultural Symposium "AGROSYM 2018". Notes: The authors declare that they have no conflicts of interest. Authorship Form signed online.
} 
Cerović and Mićić (1996) and Hedhly et al. (2005) point out the significant influence of interaction between polleniser genotype and environmental factors, while Radičević et al. (2016) emphasize the impact of polleniser, its requirement to temperatures during flowering, the influence of pollinated cultivar on pollen performance, and the response of male-female relations to air temperature.

The final phases of the pollen tubes growth occur in the tissue of the ovary. When the pollen tube enters the locule, they grow further along the placenta, through the obturator and through the micropyle into the nucellus, and then through one of the synergids in the embryo sac, penetrates the ovule and achieves fertilisation. Opposite the aforementioned in some cases, pollen tubes lose direction and do not achieve fertilisation (Herrero, 2000). The appearance of the so-called specific growth of pollen tubes in the ovary, deviating from the normal or usual was observed and described in some species of the Prunus genus, (Cerović, 1996; Hedhly et al., 2009; Đorđević et al., 2010; Radičević et al., 2016). This kind of pollen tubes growth has been described as chaotic, specific growth or growth abnormalities (Herrero, 2000). This phenomenon was firstly described as some kind of incompatibility in the ovary (Sage et al., 1994). Later, the occurrence of unusual growth of pollen tubes in the ovary was also observed in cases of pollination of compatible genotypes (Herrero, 2000). Today, after it has been proven that several structures all along the pollen tube pathway are involved in regulation of pollen tube growth (Yadegari and Drewsb, 2004; Palanivelu and Tsukamoto, 2011), the occurrence of unusual growth is explained by three main reasons. One relates to developmental changes in the female tissues and how they affect pollen tube growth (Herrero, 2001). The second refers to mutations, which disrupt pollen tubes guidance and cause pollen tubes to migrate aberrantly (Hülskamp et al., 1995; Ray et al., 1997) while the third is concerned with potential molecules involved in this signalling (Johnson and Preuss, 2002).

The aim of this study was to determine the appearance of the unusual pollen tubes growth in the ovary of the plum hybrids 38/62/70, IV/63/81, 32/21/87, 34/41/87 and 22/17/87 and plum cultivar 'Nada' in different pollination variants as well as their possible effect on achieved fertilisation.

\section{Plant material and experimental design \\ MATERIAL AND METHODS}

The research was carried out over a three-year period (2009-2011) at the experimental plum orchard at the Ljubic facility of the Fruit Research Institute, Čačak. The orchard was set up in spring 2002, using standard one-year old plantings of hybrids 38/62/70, IV/63/81, 32/21/87, 34/41/87 and 22/17/87 and cultivar 'Nada'. Myrobalan (Prunus cerasifera Ehrh.) seedling was used as a rootstock. The planting was performed at $6 \times 5$ m planting distance (333 trees ha' ${ }^{1}$ ), using the random block system with five trees in three replications. The cultivation system is the Central Leader, and the standard cultural practices were performed in the orchard. The appearance of unusual growth of pollen tubes in 
the ovary of abovementioned plum genotypes was conducted in three pollination variants: self-, cross- and open pollination. The cross-pollination was performed using the pollen of plum cultivar 'Čačanska Lepotica'.

\section{Pollination procedure and pistil sampling}

Three years old and younger branches were chosen on the trees under field conditions and flowers at the late balloon stage were emasculated, while other flowers were removed. Emasculated flowers were isolated in parchment bags. At the beginning of full flowering, when stigma receptivity was visible, pistils of each genotype were hand-pollinated by their own pollen (self- pollination) or pollen of cultivar 'Čačanska Lepotica' (cross-pollination). Pollinated pistils were isolated again by parchment bags during three weeks after pollination. For the open pollination variant branches with flowers at the beginning of full flowering stage were also chosen but without emasculation and isolation. A total of 30 pistils of each genotype per each pollination variant were fixed in FPA fixative (formaldehyde, propionic acid, 70\% ethanol in a volume ratio of 5:5:90) in three terms: $72 \mathrm{~h}, 144 \mathrm{~h}$ and $240 \mathrm{~h}$ after pollination. The aniline blue staining was used (Kho and Baër, 1968). Further methodology involved: separation of the style from the ovary; separation of the ovary along the suture; longitudinal and tangential sections of the ovule for better observation of pollen tube penetration into the micropyle and nucellus of the ovule (Cerović and Ružić, 1992). Observation of ovaries was done under UV light on Olympus BX61 microscope (Tokyo, Japan). Multiple Image Analysis software (Münster, Germany) was used to obtain an image of the entire ovary. The number of pistils (\%) with the occurrence of unusual growth of pollen tubes in each pollination variant represents the sum values for all three fixing terms. The average values for examination period were presented in the paper. The occurrence of unusual growth of pollen tubes was analyzed with respect to whether or not pollen tubes penetrated into the nucellus.

\section{RESULTS AND DISCUSSION}

The presence of pollen tubes whose growth towards the nucellus deviated from the normal was observed in the regions of the obturator or/and mycropyle of all studied plum genotypes and in all variants of pollination. Several different types of unusual growth of pollen tubes were observed, i.e. the growth of pollen tubes in opposite direction in relation to the nucellus, the curling up and branching of pollen tubes, as well as combinations of some of above mentioned types of specific growth of pollen tubes (Fig. 1 a-e). In some cases, further growth of pollen tubes towards the nucelleus was not observed (Fig. 1-a, 1-b and 1-d), resulting in the absence of fertilization, although the pollen tubes were present in the ovary.

On the other hand, the occurrence of unusual pollen tubes growth with further growth of pollen tubes and their penetration into the nucellus was observed more often (Fig. 1-c and 1-e). Similar types of unusual growth of pollen 
tubes were observed by Đorđević et al. (2010) in plum, as well as by Radičević (2013) in sweet cherry.
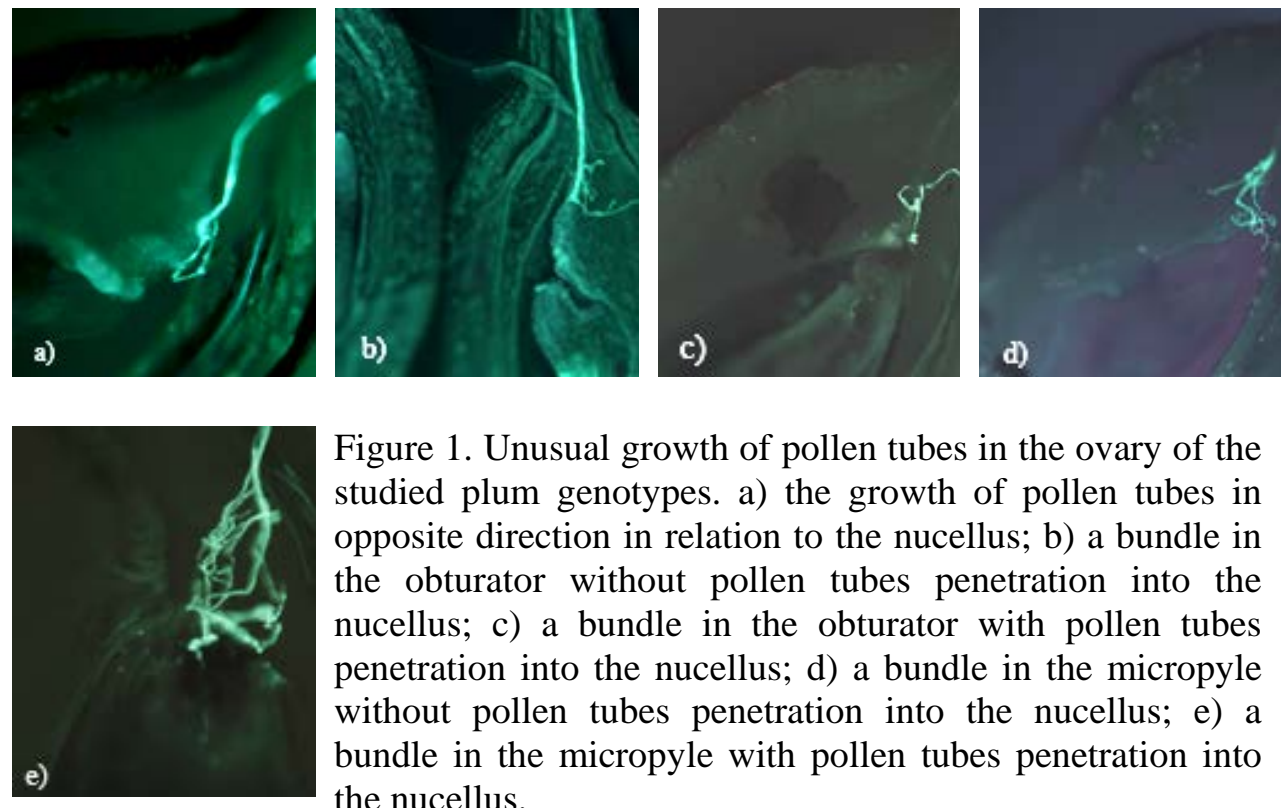

Figure 1. Unusual growth of pollen tubes in the ovary of the studied plum genotypes. a) the growth of pollen tubes in opposite direction in relation to the nucellus; b) a bundle in the obturator without pollen tubes penetration into the nucellus; c) a bundle in the obturator with pollen tubes penetration into the nucellus; d) a bundle in the micropyle without pollen tubes penetration into the nucellus; e) a bundle in the micropyle with pollen tubes penetration into the nucellus.

Table 1. Unusual growth of pollen tubes in the ovary of the studied plum genotypes in the variant of self-pollination.

\begin{tabular}{|l|c|c|c|c|}
\hline \multirow{2}{*}{ Genotyp } & \multicolumn{2}{|c|}{ Obturator } & \multicolumn{2}{c|}{ Micropyle } \\
\cline { 2 - 5 } & *PTDPN (\%) & **PTPN (\%) & *PTDPN (\%) & $\begin{array}{c}\text { **PTPN } \\
\text { (\%) }\end{array}$ \\
\hline $\begin{array}{l}\text { Hybrid } \\
\text { 38/62/70 }\end{array}$ & 3.76 & 2.46 & 0.00 & 3.34 \\
\hline $\begin{array}{l}\text { Hybrid } \\
\text { IV/63/81 }\end{array}$ & 0.00 & 0.00 & 0.95 & 4.92 \\
\hline $\begin{array}{l}\text { Hybrid } \\
\text { 32/21/87 }\end{array}$ & 0.00 & 0.00 & 0.51 & 0.00 \\
\hline Nada & 1.55 & 0.00 & 0.00 & 0.00 \\
\hline $\begin{array}{l}\text { Hybrid } \\
\text { 34/41/87 }\end{array}$ & 0.00 & 0.70 & 3.32 & 2.95 \\
\hline $\begin{array}{l}\text { Hybrid } \\
\text { 22/17/87 }\end{array}$ & 0.00 & 0.60 & 6.79 & 5.60 \\
\hline Average & 0.44 & 0.31 & 0.96 & 1.41 \\
\hline
\end{tabular}

*PTDPN - Ovaries where pollen tubes did not penetrate into the nucellus

**PTPN - Ovaries where pollen tubes penetrated into the nucellus

The average values for all analyzed genotypes (Tables 1-3) point that the highest frequency of the ovaries with unusual growth of pollen tubes was determined in the open pollination variant $(7.89 \%)$, followed by the cross- 
pollination variant (6.27\%), while the smallest frequency was found in the selfpollination variant (3.12\%). These results are in agreement with the results of Radović et al. (2017), but in contrast with the results of Đorđević et al. (2010) who have found that the occurrence of the unusual pollen tubes growth in the ovary was more frequent in self-pollination variant compared to open-pollination variant.

Table 2. Unusual growth of pollen tubes in the ovary of the studied plum genotypes in the variant of open-pollination.

\begin{tabular}{|l|c|c|c|c|}
\hline \multirow{2}{*}{ Genotyp } & \multicolumn{2}{|c|}{ Obturator } & \multicolumn{2}{c|}{ Micropyle } \\
\cline { 2 - 5 } & *PTDPN (\%) & **PTPN (\%) & *PTDPN (\%) & $\begin{array}{c}\text { **PTPN } \\
\text { (\%) }\end{array}$ \\
\hline $\begin{array}{l}\text { Hybrid } \\
\text { 38/62/70 }\end{array}$ & 2.42 & 1.61 & 1.82 & 5.72 \\
\hline $\begin{array}{l}\text { Hybrid } \\
\text { IV/63/81 }\end{array}$ & 0.00 & 0.85 & 2.94 & 3.57 \\
\hline $\begin{array}{l}\text { Hybrid } \\
\text { 32/21/87 }\end{array}$ & 0.70 & 1.17 & 0.66 & 1.56 \\
\hline Nada & 0.00 & 0.00 & 1.41 & 4.74 \\
\hline $\begin{array}{l}\text { Hybrid } \\
\text { 34/41/87 }\end{array}$ & 0.00 & 1.90 & 2.13 & 3.01 \\
\hline $\begin{array}{l}\text { Hybrid } \\
\text { 22/17/87 }\end{array}$ & 0.40 & 0.36 & 4.89 & 5.48 \\
\hline \multicolumn{1}{c|}{ Average } & 0.59 & 0.98 & 2.31 & 4.01 \\
\hline
\end{tabular}

*PTDPN - Ovaries where pollen tubes did not penetrate into the nucellus

**PTPN - Ovaries where pollen tubes penetrated into the nucellus

On average, all pollination variants were characterized by the largest number of pollen tubes with unusual growth in the region of the mycropile, where there was penetration of pollen tubes into the nucellus. This rule was typical for all of the studied plum genotypes in the variant of open-pollination, but not for two other pollination variants.

For example, the largest number of pollen tubes with unusual growth in the region of obturator without pollen tubes penetration into the nucellus was observed in the ovaries of hybrid 38/62/70 (3.76) and cultivar Nada (1.55) in the variant of self-pollination as well as in the ovaries of hybrid 38/62/70 (5.89) in the variant of cross-pollination (Tables 1 and 3). Also, hybrids 34/41/87 and $22 / 17 / 87$ in the variant of self-pollination (3.32; 6.79, respectively) and hybrid $32 / 21 / 87$ in the variant of cross-pollination (5.63) had the largest number of ovaries with unusual pollen tubes growth in the micropyle region, where there was no further growth of pollen tubes (Tables 1 and 3).

The appearance of unusual pollen tubes growth in ovary without their further growth towards the nucellus of studied plum genotypes, lead to the absence of fertilization in a certain percentage of ovules. This phenomenon was 
most prevalent in hybrid 22/17/87 in variants of self- and open-pollination and in hybrids 38/62/70 and 32/21/87 in the variant of cross-pollination.

Table 3. Unusual growth of pollen tubes in the ovary of the studied plum genotypes in the variant of cross-pollination.

\begin{tabular}{|l|c|c|c|c|}
\hline \multirow{2}{*}{ Genotyp } & \multicolumn{2}{|c|}{ Obturator } & \multicolumn{2}{c|}{ Micropyle } \\
\cline { 2 - 5 } & *PTDPN (\%) & **PTPN (\%) & *PTDPN (\%) & $\begin{array}{c}\text { **PTPN } \\
\text { (\%) }\end{array}$ \\
\hline $\begin{array}{l}\text { Hybrid } \\
\text { 38/62/70 }\end{array}$ & 5.89 & 0.00 & 0.86 & 0.00 \\
\hline $\begin{array}{l}\text { Hybrid } \\
\text { IV/63/81 }\end{array}$ & 0.37 & 0.97 & 1.87 & 3.79 \\
\hline $\begin{array}{l}\text { Hybrid } \\
\text { 32/21/87 }\end{array}$ & 0.00 & 1.22 & 5.63 & 0.00 \\
\hline Nada & 0.00 & 0.00 & 0.00 & 4.85 \\
\hline $\begin{array}{l}\text { Hybrid } \\
34 / 41 / 87\end{array}$ & 0.00 & 0.00 & 0.00 & 2.39 \\
\hline $\begin{array}{l}\text { Hybrid } \\
\text { 22/17/87 }\end{array}$ & 3.90 & 0.00 & 3.50 & 2.20 \\
\hline \multicolumn{1}{|c|}{ Average } & 1.69 & 0.39 & 1.98 & 2.21 \\
\hline
\end{tabular}

*PTDPN - Ovaries where pollen tubes did not penetrate into the nucellus

**PTPN - Ovaries where pollen tubes penetrated into the nucellus

Results of our study showed that some pollen tubes followed a route and penetrated nucellus, while others lost their orientation and grew chaotic. The first place where unusual growth of pollen tubes was observed was obturator while the second place was micropyla. The obturator is placental protuberance and represents some kind of bridge between the stylar transmitting tissue and the ovule entrance. This region of ovary is first critical territory or place of the first stop of pollen tubes. Pollen tubes growth is not possible until this structure enters a secretory phase. In some species like kiwi fruit, a secretion phase of obturator starts from flower opening (González et al., 1996). In contrast, secretory phase of obturator cells of peach starts 12 days after anthesis (Arbeloa and Herrero, 1987). In the ovary of sour cherry, the occurrence of specific pollen tube growth was first observed in the region of the obturator, with starch grain found in its cells (Cerović, 1994).

The newest results obtained in apple emphasize that the arrival of pollen tubes at the obturator was followed by secretion of proteins, saccharides and glycoproteins as well as that following pollen tube passage, these glycoproteins were exhausted (Lossada and Herrero, 2017). The embryo sac is required for directing pollen tubes during late stages of its growth (Johnson and Preuss, 2002). Dramatic defect in direction of pollen tube growth in the region of micropyla was obtained when the synergid cells were ablated (Higashiyama et al., 2001). 


\section{CONCLUSIONS}

The occurrence of unusual growth of pollen tubes in the ovary, in the region of the obturator and the micropyle, with or without further growth of the pollen tubes to the nucellus, was observed in all of the studied genotypes and in all pollination variants.

The highest frequency of the ovaries with unusual growth of pollen tubes was determined in the open pollination variant, followed by the cross-pollination variant, while the smallest frequency was found in the self-pollination variant. All pollination variants were characterized by the largest number of pollen tubes with unusual growth in the region of the mycropile, where there was penetration of pollen tubes into the nucellus.

The phenomenon of the unusual growth of pollen tubes in the ovary without further growth of the pollen tubes to the nucellus of some of examined plum cultivars resulted in the absence of fertilization, although the pollen tubes were present in the ovary.

\section{ACKNOWLEDGEMENTS}

This paper is supported by the grant of Ministry of Education, Science and Technological Development of the Republic of Serbia, Project No 31064.

\section{REFERENCES}

Arbeloa A., Herrero M. (1987). The significance of the obturator in the control of pollen tube entry into the ovary in peach (Prunus persica), Annals of Botany, 60 (1), 681-685.

Cerović, R. (1994). Histocitološki aspekti dinamike oplodnje kod višnje (Prunus cerasus L.), PhD Thesis, University of Belgrade, Faculty of Agriculture, Belgrade.

Cerović R. (1996). Unusual behavior of growing pollen tubes in the ovary of sour cherry, Acta Horticulturae, 423, 171-176.

Cerović R., Ružić Đ. (1992). Senescence of ovules at different temperatures and their effect on the behavior of pollen tubes in sour cherry, Scientia Horticulturae, 51, 321-327.

Cerović R., Mićić N. (1996). Pollination and fertilization of pome and stone fruit, Journal of Pomology, 30 (113-114), 73-98.

Đorđević M., Cerović R., Nikolić D., Radičević S. (2010). Unusual behaviour of growing pollen tubes in the ovary of plum culture (Prunus domestica L.), Archives of Biological Sciences, 62 (1), 137-142.

González M.V., Coque M., Herrero M. (1996). Pollen-pistil interaction in kiwifruit (Actinidia deliciosa; Actinidiaceae), American Journal of Botany, 83,148-154.

Hedhly A., Hormaza J.I., Herrero M. (2005). Influence of genotype-temperature interaction on pollen performance, Journal of Evolutionary Biology, 18 (6), 14941502.

Hedhly A., Hormaza J.I., Herrero M. (2009). Flower emasculation accelerates ovule degeneration and reduces fruit set in sweet cherry, Scientia Horticulturae, 119, 455-457.

Herrero M. (2000). Changes in the ovary related to pollen tube guidance, Annals of Botany, 85 (1), 79-85. 
Herrero M. (2001). Ovary signals for directional pollen tube growth, Sexual Plant Reproduction, 14, 3-7.

Higashiyama T., Yabe S., Sasaki N., Nishimura Y., Miyagishima S., Kuroiwa H., Kuroiwa T. (2001). Pollen tube attraction by the synergid cell, Science, 293, 1480-1483.

Hülskamp, M., Schneitz, K., Pruitt, R. (1995). Genetic evidence for a long-range activity that directs pollen tube guidance in Arabidopsis, Plant Cell 7, 57-64.

Johnson M. A., Preuss D. (2002). Plotting a course: multiple signals Guide Pollen Tubes to Their Targets, Developmental Cell, 2, 273-281.

Kho Y.O., Baër J. (1968). Observing pollen tubes by means of fluorescence, Euphytica 17, 298-302.

Lossada J.M., Herrero M. (2017). Pollen tube access to the ovule is mediated by glycoprotein secretion on the obturator of apple (Malus $\times$ domestica, Borkh), Annals of Botany, 119 (6), 989-1000.

Neumüller M. (2010). Fundamental and applied aspects of plum (Prunus domestica L.) breeding. In: Flachowsky H., Hanke V.M. (Eds), 'Methods in temperate fruit breeding', Fruit, vegetable and cereal science and biotechnology, Global Science Books, Kagawa, Japan, 5 (1), 139-154.

Palanivelu, R., Tsukamoto, T. (2011). Pathfinding in angiosperm reproduction: pollen tube guidance by pistils ensures successful double fertilization, WIREs Developmental Biology, 1 (1), 96-113.

Radičević S. (2013). Fertilization biology and pomological properties of newly introduced sweet cherry (Prunus avium L.) cultivars, PhD Thesis, University of Belgrade, Faculty of Agriculture, Belgrade.

Radičević S., Cerović R., Nikolić D., Đorđević M. (2016). The effect of genotype and temperature on pollen tube growth and fertilization in sweet cherry (Prunus avium L.), Euphytica, 209, 121-136.

Radović A., Nikolić D., Cerović R., Milatović D., Đorđević B., Zec G. (2017). Unusual growth of pollen tubes in the ovary of quince (Cydonia oblonga mill.), Acta Scientiarum Polonorum Hortorum Cultus, 16 (2), 133-138.

Ray, S.M., Park, S.S., and Ray, A. (1997). Pollen tube guidance by the female gametophyte, Development 124, 2489-2498.

Sage T.L., Bertin R.I., Williams E.G. (1994). Ovarian and other late-action selfincompatibility systems, In: Williams E.G., Clarke A.E., and. Knox R.B. (Eds.), Genetic control of self-incompatibility and reproductive development in flowering plants, Kluwer Academic Publishers, Dordrecht, Netherlands, pp. 116-140.

Stott K.G., Jefferies C.J., Jago C. (1973). Pollination and fruit set in plum, Report of Long Ashton Research Station for 1972, University of Bristol, pp. 23-26.

Yadegari R., Drewsb N.G. (2004). Female gametophyte development, The Plant Cell, 16, 133-141. 